Journal of Applied Pharmaceutical Science Vol. 7 (07), pp. 225-229, July, 2017

Available online at http://www.japsonline.com

DOI: $10.7324 / J A P S .2017 .70733$

ISSN 2231-3354 (cc) BY-NC-SA

\title{
Antioxidant, anti-tyrosinase and anti-quorum sensing activities of four mangrove tree species vs. green tea
}

\author{
Eric Wei Chiang Chan*, Sin Mei Ng, Bexter Wee Kiong Sim, Huey Chee Tan, Zen Loong Lo \\ Faculty of Applied Sciences, UCSI University, Cheras 56000, Kuala Lumpur, Malaysia.
}

\begin{tabular}{|c|c|}
\hline ARTICLE INFO & ABSTRACT \\
\hline $\begin{array}{l}\text { Article history: } \\
\text { Received on: } 22 / 10 / 2016 \\
\text { Accepted on: } 08 / 01 / 2017 \\
\text { Available online: } 30 / 07 / 2017\end{array}$ & $\begin{array}{l}\text { This study was conducted to validate a claim that mangrove teas have stronger antioxidant and anti-tyrosinase } \\
\text { properties than green tea. Different plant parts (leaves, stems and roots) of four mangrove tree species namely } \\
\text { Rhizophora apiculata, Rhizophora stylosa, Avicennia rumphiana and Sonneratia alba were analysed their } \\
\text { antioxidant, anti-tyrosinase and anti-quorum sensing (anti-QS) properties. Strongest antioxidant properties were }\end{array}$ \\
\hline $\begin{array}{l}\text { Key words: } \\
\text { Rhizophora apiculata, } \\
\text { Rhizophora stylosa, } \\
\text { Avicennia rumphiana, } \\
\text { Sonneratia alba, } \\
\text { Camellia sinensis. }\end{array}$ & $\begin{array}{l}\text { teas (dried leaves) were inferior to leaves of Camellia sinensis and green tea, respectively. The anti-tyrosinase } \\
\text { activity of leaves and stems of } R \text {. apiculata, and stems of } S \text {. alba was outstanding but was not detected in green } \\
\text { tea. All four mangrove species possessed anti-QS properties with moderate activity displayed by green tea. }\end{array}$ \\
\hline
\end{tabular}

\section{INTRODUCTION}

Mangroves are tidal forests of the tropics and subtropics that thrive in sheltered coastal areas such as estuaries, accreting shores, bays and lagoons (Giesen et al., 2007). These plant communities also occur in areas protected by sand bars, islands, coral reefs and/or sea grasses. At the seafront, trees such as Avicennia and Sonneratia with their extensive pneumatophores contribute to land accretion by colonising and stabilising the mudflats. On firmer and more compact sediments further inland, trees of Rhizophora with stilt roots and Bruguiera with knee roots dominate. Where large rivers occur, mangroves may extend upstream for tens of kilometres, merging into freshwater swamp forests. As a background to this paper, a recent article in the Asian Pacific Journal of Tropical Medicine by Suh et al. (2014) reported a controversial finding that the antioxidant and anti-tyrosinase properties of two mangrove tree species (Rhizophora stylosa Griff.

\footnotetext{
* Corresponding Author

Eric Wei Chiang Chan, Faculty of Applied Sciences, UCSI University, Cheras, Kuala Lumpur, Malaysia. Email: erchan @ yahoo.com
}

and Sonneratia alba J.E. Smith) sampled from Micronesia were stronger than those of green tea of Camellia sinensis (L.) Kuntze. In an attempt to validate this doubtful finding, we selected four mangrove species including $R$. stylosa and $S$. alba, and analysed their antioxidant, anti-tyrosinase and anti-quorum sensing properties. Rhizophora apiculata, B1. and Avicennia rumphiana Hallier f. (previously known as Avicennia lanata Ridley) were the other two mangrove species studied, and green tea was used as comparison. Anti-quorum sensing was also assessed in this study since the bark extract of Rhizophora annamalayana Kathir. (Musthafa et al., 2013), and the leaf extracts of Rhizophora mucronata Lamk. and R. apiculata (Annapoorani et al., 2013) have been reported to possess positive activity. Of the four species studied, the metabolites and bioactivities of $R$. apiculata and $R$. stylosa have been reviewed (Nebula et al., 2013; Kainuma et al., 2015). Characteristic features are prop or stilt roots of $R$. apiculata and $R$. stylosa, and pneumatophores of S. alba and A. rumphiana. Flowers of $R$. apiculata are always in pairs, flowers of $R$. stylosa have an elongated style, leaves of $S$. alba are leathery with a rounded apex and leaves of $R$. rumphiana have a dense hairy under-surface. 


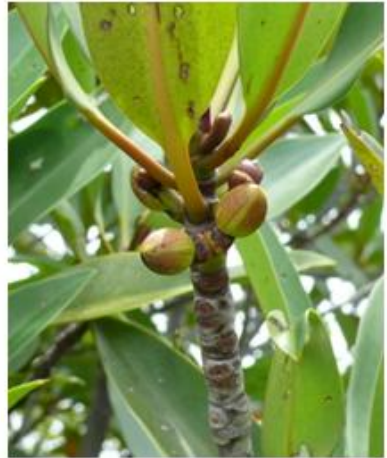

Rhizophora apiculata

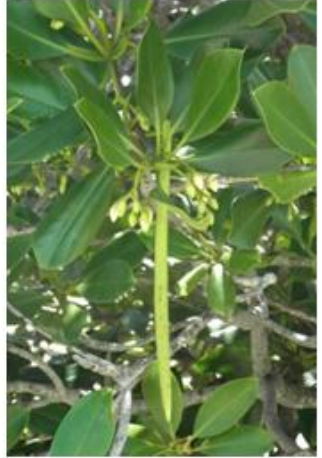

Rhizophora stylosa

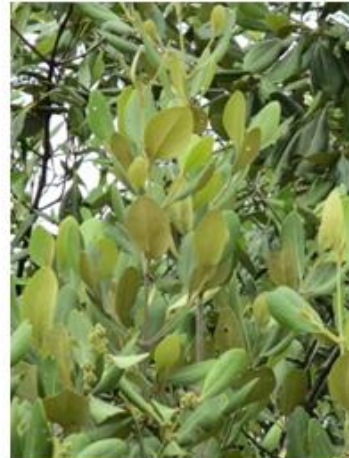

Avicennia rumphiana

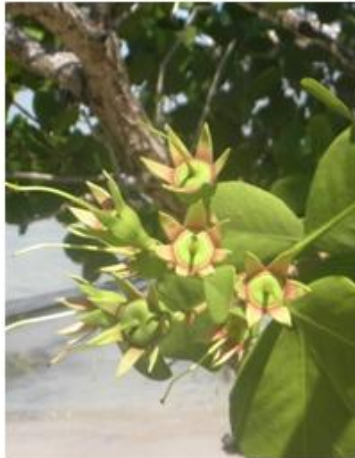

Sonneratia alba

Fig. 1: The four mangrove species studied.

\section{MATERIALS AND METHODS}

\section{Sampling in the field}

Bagan Lalang $\left(2^{\circ} 35^{\prime} \mathrm{N}, 101^{\circ} 41^{\prime} \mathrm{E}\right)$ is a popular beach resort in the southernmost part of the state of Selangor in West Malaysia. Leaves, stems and roots of $R$. apiculata, $R$. stylosa and $S$. alba were collected from scattered trees growing on sand flats at the seafront, east of the Golden Palm Tree Resort. Samples of A. rumphiana were collected from trees growing in clusters further inland. Dr Chan Hung Tuck, a mangrove expert and Executive Committee Member of the International Society for Mangrove Ecosystems (ISME) based in Okinawa, Japan, was present during the field trip to personally confirm the identity of the species. Photographs of these four species are shown in Figure 1. Stems were twigs after removal of leaves. Roots of $R$. apiculata, and $R$. stylosa were aerial stilt roots while those of $S$. alba and A. rumphiana were pneumatophores protruding from the ground.

\section{Extraction of fresh plant samples}

For antioxidant properties, fresh plant samples $(1.0 \mathrm{~g})$ were powdered with liquid nitrogen in a mortar and extracted with $50 \mathrm{ml}$ of methanol with continuous shaking for one hour at room temperature. Extracts were filtered under suction and stored at $4{ }^{\circ} \mathrm{C}$ for further analysis. For anti-tyrosinase and anti-quorum sensing activities, fresh samples $(10 \mathrm{~g})$ were similarly extracted with $100 \mathrm{ml}$ of methanol, three times for one hour each time of methanol, three times for one hour each time. After swirling continuously in an orbital shaker, the extracts were filtered and stored at $4 \mathrm{oC}$ for further analysis.

\section{Extraction of dried leaf samples}

Mangrove leaves $(20 \mathrm{~g})$ were dried at $50^{\circ} \mathrm{C}$ in a conventional oven for three hours and in a microwave oven for 40 sec. The oven-dried (OD) and microwave-dried (MD) leaves were extracted using the hot water method (Chan et al., 2011, 2012a). Samples (0.3 g) were ground and extracted with $50 \mathrm{ml}$ of boiling water with continuous swirling at $100 \mathrm{rpm}$ in an orbital shaker for one hour. The hot water was allowed throughout the extraction process to mimic the tea brewing process. After filtration, the residues were re-extracted again, dried using a freeze dryer and kept in a freezer for further analysis. Similarly $0.3 \mathrm{~g}$ of the green tea of $C$. sinensis purchased from Marks and Spencer was extracted with hot water.

\section{Antioxidant properties}

Samples were analysed for total phenolic content (TPC) using the Folin-Ciocalteu assay (Chan et al., 2012b, 2012c). Absorbance was measured at $765 \mathrm{~nm}$ and TPC was expressed as gallic acid equivalent (GAE) in $\mathrm{mg}$ per $100 \mathrm{~g}$ of sample. Antioxidant activity of free radical scavenging (FRS) ability of samples was assessed using the 2,2-diphenyl-1-picrylhydrazyl (DPPH) assay. Absorbance was measured at $517 \mathrm{~nm}$ and expressed as ascorbic acid equivalent antioxidant capacity (AEAC) in $\mathrm{mg}$ ascorbic acid (AA)/100 $\mathrm{g}$ of sample.

\section{Anti-tyrosinase activity}

Anti-tyrosinase activity of samples was determined using the modified dopachrome method with L-DOPA as substrate (Masuda et al., 2005; Chan et al., 2008, 2015). The assay was conducted in a 96-well microtiter plate and absorbance was measured at $475 \mathrm{~nm}$ with $700 \mathrm{~nm}$ as the reference. Results were compared with a control consisting of $50 \%$ DMSO and tyrosinase inhibition was calculated as $\left(\mathrm{A}_{\text {control }}-\mathrm{A}_{\text {sample }}\right) / \mathrm{A}_{\text {control }} \times 100 \%$.The concentration of extracts used for determining tyrosinase inhibition was $0.25 \mathrm{mg} / \mathrm{ml}$.

\section{Anti-quorum sensing activity}

Following the procedures described by Blosser and Gray (2000), the violacein inhibition assay was used to assess antiquorum sensing (anti-QS) activity of samples against Chromobacterium violaceum (wild type, ATCC 12472). Sample extracts were dissolved in methanol to produce stock solutions of $5.0 \mathrm{mg} / \mathrm{ml}$. Stock solutions $(0.5 \mathrm{ml})$ were transferred onto sterile Petri dishes with $4.5 \mathrm{ml}$ of fresh nutrient broth inoculated with $C$. 
violaceum $\left(\mathrm{OD}_{720} 0.100 \mathrm{~A}\right.$, which corresponded to $1.5 \times 10^{7}$ $\mathrm{cfu} / \mathrm{ml})$. The Petri dishes were incubated for $24 \mathrm{~h}$ at $26^{\circ} \mathrm{C}$ with gentle swirling at $100 \mathrm{rpm}$ before the cell density was measured at $\mathrm{OD}_{720}$. A streak plate of each Petri dish was done to ensure no contamination and that the optical density was a valid representation of cell density. To measure violacein production, $2.0 \mathrm{ml}$ of broth culture was centrifuged at $13000 \mathrm{rpm}$ for $15 \mathrm{~min}$ to recover the $C$. violaceum cells. Violacein was then extracted using $2.0 \mathrm{ml}$ of butanol with sonication and absorbance of the extracted violacein was measured at $577 \mathrm{~nm}\left(\mathrm{~A}_{577}\right)$ against a blank solution of butanol. Violacein production was expressed in terms of violacein units (VU) calculated as the ratio of $\mathrm{A}_{577} / \mathrm{OD}_{720}$. The lower the ratio value, the stronger is the anti-QS activity.

\section{Statistical analysis}

All experiments were done in triplicate $(n=3)$ and results were expressed as mean \pm standard deviation (SD). Analysis of variance (ANOVA) was analysed using the Tukey Honestly Significant Difference (HSD) test with significant difference at $p<0.05$.

\section{RESULTS AND DISCUSSION}

Based on TPC and AEAC of different plant parts of the four mangrove species, the ranking was $R$. stylosa $>R$. apiculata $>S$. alba $>$ A. rumphiana (Table 1). At the species level, highest values were obtained from the stems of $R$. stylosa, roots of $R$. apiculata and S. alba, and leaves of A. rumphiana.

Table 1: Total phenolic content and free radical scavenging activity of four mangrove tree species (fresh weight).

\begin{tabular}{|c|c|c|c|}
\hline $\begin{array}{l}\text { क्षै } \\
\text { कै }\end{array}$ & $\stackrel{\vec{E}}{\vec{E}}$ & 넙 & 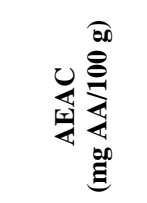 \\
\hline \multirow{3}{*}{ Rhizophora apiculata } & $\mathrm{L}$ & $2790 \pm 94 c$ & $3320 \pm 193 c$ \\
\hline & $\mathrm{S}$ & $3320 \pm 29 b$ & $3750 \pm 170 b$ \\
\hline & $\mathrm{R}$ & $3860 \pm 212 \mathrm{a}$ & $4250 \pm 245 a$ \\
\hline \multirow{3}{*}{ Rhizophora stylosa } & $\mathrm{L}$ & $2090 \pm 176 \mathrm{c}$ & $2570 \pm 148 \mathrm{c}$ \\
\hline & $\mathrm{S}$ & $6440 \pm 387 a$ & $11660 \pm 547 a$ \\
\hline & $\mathrm{R}$ & $3950 \pm 231 b$ & $7350 \pm 329 b$ \\
\hline \multirow{3}{*}{ Avicennia rumphiana } & $\mathrm{L}$ & $1300 \pm 21 \mathrm{a}$ & $1040 \pm 69 a$ \\
\hline & $\mathrm{S}$ & $432 \pm 65 b$ & $485 \pm 15 b$ \\
\hline & $\mathrm{R}$ & $352 \pm 51 \mathrm{~b}$ & $289 \pm 5 c$ \\
\hline \multirow{3}{*}{ Sonneratia alba } & $\mathrm{L}$ & $1660 \pm 175 b$ & $2770 \pm 166 b$ \\
\hline & $\mathrm{S}$ & $1400 \pm 129 b$ & $2880 \pm 212 b$ \\
\hline & $\mathrm{R}$ & $2210 \pm 200 \mathrm{a}$ & $4320 \pm 303 \mathrm{a}$ \\
\hline
\end{tabular}

Data on phenolic contents in fresh weight are means \pm standard deviations. Abbreviations: $\mathrm{L}=$ leaves, $\mathrm{S}=$ stems, $\mathrm{R}=$ roots, $\mathrm{TPC}=$ total phenolic content $(\mathrm{mg} \mathrm{GAE} / 100 \mathrm{~g}), \mathrm{AEAC}=$ ascorbic acid equivalent antioxidant capacity, GAE $=$ gallic acid equivalent and $\mathrm{AA}=$ ascorbic acid. Within each column of each species, different letters $(\mathrm{a}-\mathrm{c})$ are significant at $p<0.05$ using the Tukey HSD test.

The antioxidant properties of the stems of $R$. stylosa are noteworthy in that their TPC and AEAC (6440 mg GAE/100 $\mathrm{g}$ and $11660 \mathrm{mg}$ AA/100 g) are significantly higher than leaves of
Lagerstroemia speciosa L. (4150 mg GAE/100 g and $6120 \mathrm{mg}$ AA/100 g) and Anacardium occidentale L. (3890 mg GAE/100 g and $6620 \mathrm{mg} \mathrm{AA} / 100 \mathrm{~g}$ ), respectively. Both L. speciosa (banaba) and A. occidentale (cashew) are known to have very strong antioxidant properties (Chan and Wong, 2015). The AEAC value of $R$. stylosa stems (11660 mg AA/100 g) is comparable to that of the highland tea plant of $C$. sinensis (11380 mg AA/100 g) reported by Chan et al. (2007).

The potent antioxidant properties of stems of $R$. stylosa could be attributed to flavanols (Li et al., 2007; Takara et al., 2008) and pentacyclic triterpenoids (Li et al., 2008). Amongst the flavanols isolated, proanthocyanidin B2, epicatechin + catechin and cinchona in Ib had DPPH radical scavenging ability with $\mathrm{IC}_{50}$ values of 4.3, 6.5 and $7.8 \mu \mathrm{g} / \mathrm{ml}$, respectively (Li et al., 2007). Proanthocyanidin B2 $(4.3 \mu \mathrm{g} / \mathrm{ml})$ with the strongest free radical scavenging activity was 4.2 times stronger than butylated hydroxytoluene $(18 \mu \mathrm{g} / \mathrm{ml})$, the positive control. Flavanols from the stems of $R$. stylosa had strong radical scavenging activity with $\mathrm{EC}_{50}$ values of 4.6-9.3 $\mu \mathrm{M}$ (Takara et al., 2008). In general, the antioxidant properties of the four mangrove species were significantly weaker than those of $C$. sinensis. TPC and AEAC values are $7590 \mathrm{mg} \mathrm{GAE} / 100 \mathrm{~g}$ and $12820 \mathrm{mg} \mathrm{AA} / 100 \mathrm{~g}$ for the highland tea plants, and $7280 \mathrm{mg}$ GAE/100 $\mathrm{g}$ and $11380 \mathrm{mg}$ AA/100 g for the lowland tea plants, respectively (Chan et al., 2007).

Table 2: Phenolic content and free radical scavenging activity of hot water tea infusions of dried mangrove leaves in comparison with green tea (dry weight).

\begin{tabular}{|c|c|c|c|}
\hline 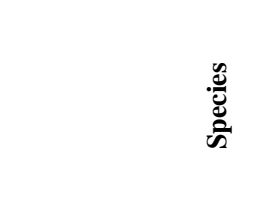 & 焉苛 & v & 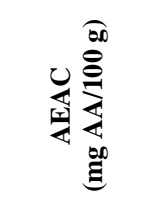 \\
\hline \multirow{2}{*}{ Rhizophora apiculata } & MD & $2820 \pm 509 a$ & $4130 \pm 263 a$ \\
\hline & OD & $3070 \pm 60 \mathrm{a}$ & $3750 \pm 99 a$ \\
\hline \multirow{2}{*}{ Rhizophora stylosa } & MD & $2650 \pm 141 \mathrm{a}$ & $3410 \pm 263 b$ \\
\hline & OD & $2360 \pm 114 a$ & $3980 \pm 167 a$ \\
\hline \multirow{2}{*}{ Avicennia rumphiana } & MD & $3940 \pm 55 a$ & $6280 \pm 505 a$ \\
\hline & OD & $2250 \pm 149 b$ & $2930 \pm 11 b$ \\
\hline \multirow{2}{*}{ Sonneratia alba } & MD & $2270 \pm 93 b$ & $3860 \pm 313 b$ \\
\hline & OD & $3570 \pm 80 \mathrm{a}$ & $6920 \pm 647 \mathrm{a}$ \\
\hline Green tea & & $6550 \pm 338$ & $11740 \pm 619$ \\
\hline \multicolumn{4}{|c|}{$\begin{array}{l}\text { Data on phenolic contents in dry weight are means } \pm \text { standard deviations. } \\
\text { Abbreviations: } \mathrm{MD}=\text { microwave-dried, } \mathrm{OD}=\text { oven-dried, TPC }=\text { total phenolic } \\
\text { content }(\mathrm{mg} \mathrm{GAE} / 100 \mathrm{~g} \text { ), AEAC }=\text { ascorbic acid equivalent antioxidant } \\
\text { capacity, GAE }=\text { gallic acid equivalent and } \mathrm{AA}=\text { ascorbic acid. Within each } \\
\text { column of each species, different letters (a-b) are significant at } p<0.05 \text { using } \\
\text { the Tukey HSD test. }\end{array}$} \\
\hline
\end{tabular}

Microwave and oven drying had variable effects on the antioxidant properties of the hot water tea infusions of mangrove leaves (Table 2). At the species level, TPC and AEAC values of MD and OD leaves were comparable for $R$. apiculata and $R$. stylosa, higher in MD leaves for A. rumphiana and higher in OD leaves for $S$. alba. The highest values of TPC (3940 mg GAE/100 g) observed in MD leaves of A. rumphiana and AEAC $(6920 \mathrm{mg}$ AA/100 g) observed in OD leaves of $S$. alba were both 1.7 times 
lower than those of green tea with TPC of $6550 \mathrm{mg}$ GAE/100 $\mathrm{g}$ and AEAC of $11740 \mathrm{mg} \mathrm{AA} / 100 \mathrm{~g}$. Finding from this study therefore contradicts the observation by Suh et al. (2014) that mangrove teas have stronger antioxidant properties than green tea, despite differences in the methods of tea preparation and in the brands of green tea used.

Of the four species, anti-tyrosinase activity was not observed all the plant parts of $R$. stylosa and A. rumphiana (Table $3)$. Strongest activity was displayed in the leaves (70\%) and stems $(70 \%)$ of $R$. apiculata, and in the stems $(62 \%)$ of $S$. alba. Expectedly, tyrosinase inhibitory activity was not detected in green tea of $C$. sinensis. If tea leaves were to possess endogenous tyrosinase inhibitors, they would prevent fermentation of leaves into black tea by polyphenol oxidase. It was noted that the values of R. apiculata and S. alba superseded those of leaves of Hibiscus tiliaceus L. (42\%) and Psidium guava L. (41\%) (Wong et al., 2010), roots of Eurycoma longifolia Jack (45\%) (Wan Hassan et al., 2015a), and pericarps of Garcinia mangostana L. (Wan Hassan et al., 2015b), which have strong anti-tyrosinase activity. Contrary to findings of this study, Suh et al. (2014) reported that leaves, stems and roots of $R$. stylosa inhibited tyrosinase with the strongest activity in the stems (90\%).

Table 3: Tyrosinase inhibition of four mangrove tree species.

\begin{tabular}{ccc}
\hline Species & Plant part & Tyrosinase inhibition (\%) \\
\hline \multirow{3}{*}{ Rhizophora apiculata } & $\mathrm{L}$ & $70 \pm 4 \mathrm{a}$ \\
& $\mathrm{S}$ & $70 \pm 7 \mathrm{a}$ \\
& $\mathrm{R}$ & $52 \pm 7 \mathrm{~b}$ \\
\hline \multirow{3}{*}{ Rhizophora stylosa } & $\mathrm{L}$ & $\mathrm{ND}$ \\
& $\mathrm{S}$ & $\mathrm{ND}$ \\
& $\mathrm{R}$ & $\mathrm{ND}$ \\
\hline \multirow{3}{*}{ Avicennia rumphiana } & $\mathrm{L}$ & $\mathrm{ND}$ \\
& $\mathrm{S}$ & $\mathrm{ND}$ \\
& $\mathrm{R}$ & $\mathrm{ND}$ \\
\hline \multirow{2}{*}{ Sonneratia alba } & $\mathrm{L}$ & $68 \pm 6 \mathrm{~b}$ \\
& $\mathrm{~S}$ & $52 \pm 6 \mathrm{a}$ \\
& $\mathrm{R}$ & $\mathrm{ND}$ \\
\hline Green tea & $\mathrm{L}$ & $\mathrm{Ab}$
\end{tabular}

Data on tyrosinase inhibition are means \pm standard deviations. Abbreviations: $\mathrm{L}=$ leaves, $\mathrm{S}=$ stems, $\mathrm{R}=$ roots and $\mathrm{ND}=$ not detected. The concentration of extracts used for determining tyrosinase inhibition was $0.25 \mathrm{mg} / \mathrm{ml}$. Within the same column, different letters (a-b) are significantly different at $p<0.05$, as measured by the Tukey's HSD test. ANOVA does not apply between species.

Data on the anti-QS activity of the four mangrove species based on optical density of inhibition of $C$. violaceum growth and violacein production are shown in Table 4. Violacein production expressed as violacein units (VU) was used to indicate quorum sensing. A good anti-QS agent should have low VU with minimal reduction in bacterial growth. Species with significantly lower VU values than the control were stems and roots of $R$. apiculata, leaves and roots of A. rumphiana, and roots of $S$. alba.

However, stems and roots of $R$. apiculata, and roots of $S$. alba also exhibited growth inhibition of $C$. violaceum as shown by their low optical density at $720 \mathrm{~nm}$, and thus VU reduction might not be solely caused by QS inhibition. Leaves and roots of $A$. rumphiana showed the greatest promise as anti-QS agents because of their low VU values and minimal impact on bacterial growth. In comparison, the anti-QS activity of green tea was moderate. Among mangrove species, anti-QS activity was reported in the bark extract of $R$. annamalayana by Musthafa et al. (2013) using the violacein inhibition assay against $C$. violaceum and the antibioluminescence assay against Vibrio harveyi. At $1.0 \mathrm{mg} / \mathrm{ml}$, the extract reduced QS-dependent factor production with no inhibitory effect on bacterial growth. Anti-QS activity against Pseudomonas aeruginosa was also reported in the leaf extracts of $R$. apiculata and $R$. mucronata (Annapoorani et al., 2013).

Table 4: Anti-quorum sensing activity of four mangrove tree species based on optical density of inhibition of Chromobacterium violaceum growth and violacein production.

\begin{tabular}{|c|c|c|c|c|}
\hline 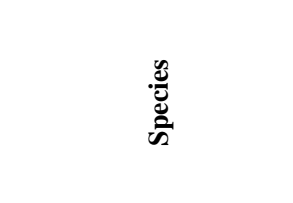 & 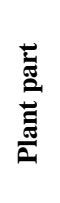 & 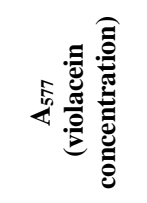 & 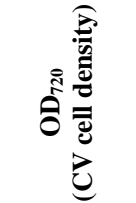 & 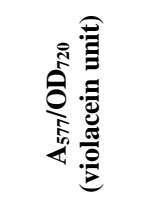 \\
\hline \multirow{3}{*}{ Rhizophora apiculata, } & $\mathrm{L}$ & $1.10 \pm 0.04$ & $0.77 \pm 0.03$ & $1.37 \pm 0.06$ \\
\hline & $\mathrm{S}$ & $0.47 \pm 0.01$ & $0.57 \pm 0.01$ & $0.82 \pm 0.01 *$ \\
\hline & $\mathrm{R}$ & $0.46 \pm 0.01$ & $0.52 \pm 0.02$ & $0.87 \pm 0.05^{*}$ \\
\hline \multirow{3}{*}{ Rhizophora stylosa } & $\mathrm{L}$ & $1.98 \pm 0.38$ & $1.24 \pm 0.17$ & $1.32 \pm 0.08$ \\
\hline & $\mathrm{S}$ & $1.34 \pm 0.28$ & $0.67 \pm 0.17$ & $1.62 \pm 0.35$ \\
\hline & $\mathrm{R}$ & $1.14 \pm 0.27$ & $0.53 \pm 0.08$ & $2.03 \pm 0.22$ \\
\hline \multirow{3}{*}{ Avicennia rumphiana } & $\mathrm{L}$ & $2.58 \pm 0.29$ & $3.00 \pm 0.29$ & $0.86 \pm 0.06^{*}$ \\
\hline & $\mathrm{S}$ & $1.76 \pm 0.42$ & $0.74 \pm 0.07$ & $2.34 \pm 0.32$ \\
\hline & $\mathrm{R}$ & $2.01 \pm 0.33$ & $1.93 \pm 0.51$ & $1.07 \pm 0.12^{*}$ \\
\hline \multirow{3}{*}{ Sonneratia alba } & $\mathrm{L}$ & $0.95 \pm 0.04$ & $0.50 \pm 0.08$ & $1.94 \pm 0.39$ \\
\hline & $\mathrm{S}$ & $0.57 \pm 0.17$ & $0.55 \pm 0.17$ & $1.14 \pm 0.56$ \\
\hline & $\mathrm{R}$ & $0.59 \pm 0.19$ & $0.66 \pm 0.08$ & $0.91 \pm 0.30^{*}$ \\
\hline Green tea & & $1.50 \pm 0.06$ & $1.33 \pm 0.01$ & $1.13 \pm 0.05^{*}$ \\
\hline Control & & $1.37 \pm 0.02$ & $0.95 \pm 0.01$ & $1.45 \pm 0.01$ \\
\hline \multicolumn{5}{|c|}{$\begin{array}{l}\text { Abbreviations: } \mathrm{L}=\text { leaves, } \mathrm{S}=\text { stems, } \mathrm{R}=\text { roots, } \mathrm{CV}=\text { Chromobacterium } \\
\text { violaceum, } \mathrm{A}=\text { absorbance and } \mathrm{OD}=\text { optical density. Values are means } \pm \\
\text { standard deviations }(n=3) \text {. Violacein concentration and } \mathrm{CV} \text { cell density were } \\
\text { measured at absorbance at } 577 \mathrm{~nm}\left(\mathrm{~A}_{577}\right) \text { and optical density at } 720 \mathrm{~nm} \\
\left(\mathrm{OD}_{720}\right) \text {, respectively. Violacein production, represented in terms of violacein } \\
\text { units }(\mathrm{VU}) \text {, was calculated as } \mathrm{A}_{577} / \mathrm{OD}_{720} \text {. Lower } \mathrm{VU} \text { values suggest stronger } \\
\text { anti-quorum sensing activity. The viable cell count for the control was } 2.8 \times \\
10^{9} \mathrm{cfu} / \mathrm{ml} \text {. The concentration of extract used for determining violacein } \\
\text { inhibition was } 0.5 \mathrm{mg} / \mathrm{ml} \text {. In the VU column of each species, values with the } \\
\text { asterisk are significant stronger than the control. }\end{array}$} \\
\hline
\end{tabular}

\section{CONCLUSION}

Strongest antioxidant properties were observed in the stems of $R$. stylosa. Antioxidant properties of the four mangrove species and their teas were strong but inferior to those of $C$. Sinensis leaves and green tea. The anti-tyrosinase activity of leaves and stems of $R$. apiculata, and stems of $S$. alba was outstanding. All four species possess anti-QS properties with moderate activity displayed by green tea. These aspects, notably the anti-tyrosinase and anti-QS properties, warrant further study.

\section{ACKNOWLEGEMENT}

The authors are most grateful to Dr Chan Hung Tuck of the International Society for Mangrove Ecosystems (ISME) for the field excursion to Bagan Lalang where the mangrove species were located, identified and sampled. 
Financial support and sponsorship: Nil.

Conflict of Interests: There are no conflicts of interest.

\section{REFERENCES}

Annapoorani A, Kalpana B, Musthafa KS, Pandian SK, Ravi AV. Anti-pathogenic potential of Rhizophora spp. against the quorum sensing mediated virulence factors production in drug resistant Pseudomonas aeruginosa. Phytomedicine, 2013; 20: 956-963.

Blosser RS, Gray KM. Extraction of violacein from Chromobacterium violaceum provides a new quantitative bioassay for $\mathrm{Na}$ cyl homoserine lactone autoinducers. J Microbiol Methods, 2000; 40: 4755 .

Chan EWC, Lim YY, Chew YL. Antioxidant activity of Camellia sinensis leaves and tea from a lowland plantation in Malaysia. Food Chem, 2007; 102: 1214-1222.

Chan EWC, Soh EY, Tie PP, Law YP. Antioxidant and antibacterial properties of green, black and herbal teas of Camellia sinensis. Pharmacogn Res, 2011; 3: 268-275.

Chan EWC, Eng SY, Tan YP, Wong ZC, Lye PY, Tan LN. Antioxidant and sensory properties of Thai herbal teas with emphasis on Thunbergia laurifolia Lindl. Chiang Mai J Sci, 2012a; 39: 599-609.

Chan EWC, Kong LQ, Yee KY, Chua WY, Loo TY. Antioxidant and antibacterial properties of some fresh and dried Labiatae herbs. Free Radic Antioxid, 2012b; 2: 20-27.

Chan EWC, Kong LQ, Yee KY, Chua WY, Loo TY. Rosemary and sage outperformed six other culinary herbs in antioxidant and antibacterial properties. Int J Biotechnol Wellness Indust, 2012c; 1: 142151

Chan EWC, Kong LQ, Yee KY, Chua WY, Loo TY. Rosemary and sage outperformed six other culinary herbs in antioxidant and antibacterial properties. Int J Biotechnol Wellness Indust,2012c; 1: 142151.

Chan EWC, Wong SK.Herbs and herbal teas with antioxidant properties comparable to or superior than those of Camellia sinensis. Int $\mathrm{J}$ Pharmacogn, 2015; 2: 33-37.

Chan EWC, Chan HJ, Lim JE, Yik SH, Tan SF, Goh PC, Yap KY, Yee SY. Effects of different cooking methods on the bioactivities of some spices. Emir J Food Agric, 2015; 27: 610-616.

Giesen W, Wulfraat S, Zieren M, Scholten, L., 2007. Mangrove Guidebook for Southeast Asia. FAO and Wetland International, 769 pp.

Kainuma M, Kezuka M, Inoue T, Chan EWC, Tangah J, Baba S, Chan HT. Botany, uses, chemistry and bioactivities of mangrove plants I: Rhizophora stylosa. ISME/GLOMIS Electron J, 2015; 13: 12-17.
Li DL, Li XM, Peng ZY, Wang BG. Flavanol derivatives from Rhizophora stylosaand their DPPH radical scavenging activity. Molecules, 2007; 12: 1163-1169.

Li DL, Li XM, Wang BG.Pentacyclic triterpenoids from the mangrove plant Rhizophora stylosa.Nat Prod Res, 2008; 22: 808-813.

Masuda T, Yamashita D, Takeda Y, Yonemori S. Screening for tyrosinase inhibitors among extracts of seashore plants and identification of potent inhibitors from Garcinia subelliptica. Biosci Biotechnol Biochem, 2005; 69: 197-201.

Musthafa KS, Sahu SK, Ravi AV, Kathiresan K. Anti-quorum sensing potential of the mangrove Rhizophora annamalayana. World J Microbiol Biotechnol, 2013; 29: 1851-1858.

Nebula M, Harisankar HS, Chandramohanakumar N. Metabolites and bioactivities of Rhizophoraceae mangroves. Nat Prod Bioprospect, 2013; 3: 207-232.

Suh SS, Hwang J, Park M, Park HS, Lee TK. Phenol content, antioxidant and tyrosinase inhibitory activity of mangrove plants in Micronesia. Asian Pac J Trop Med,2014;531-535.

Takara K, Kuniyoshi A, Wada K, Kinjyo K, Iwasaki H. Antioxidative flavan-3-ol glycosides from stems of Rhizophora stylosa Biosci Biotechnol Biochem, 2008; 72: 2191-2194.

Wan Hassan WNA, Zulkifli RM, Ahmad F, CheYunus MA. Antioxidant and tyrosinase inhibition activities of Eurycoma longifolia and Swietenia macrophylla. J Appl Pharm Sci, 2015a; 5: 6-10.

Wan Hassan WNA, Zulkifli RM, Basar N, Ahmad F, CheYunus MA. Antioxidant and tyrosinase inhibition activities of $\alpha$-mangostin and Garcinia mangostana Linn.pericarp extracts. J Appl Pharm Sci, 2015b; 5: $37-40$.

Wong SK, Lim YY, Chan EWC. Evaluation of antioxidant anti-tyrosinase and antibacterial activities of selected Hibiscus species. Ethnobot Leaflet, 2010; 14: 781-796.

How to cite this article:

Chan EWC, Ng SM, Sim BWK, Tan HC, Lo ZL. Antioxidant, antityrosinase and anti-quorum sensing activities of four mangrove tree species vs. green tea. J App Pharm Sci, 2017; 7 (07): 225-229. 